\title{
The Adaptation of New Countries to Existing (Old) Institutional Frameworks
}

\author{
Erkki Berndtson
}

\section{In Search of European Political Science}

Political science is a relatively young discipline. As an independent academic subject, it only emerged in Europe after the Second World War. Moreover, up until the 1990s, political science was mainly a preserve of Western Europe. The discipline began to develop in Central and Eastern Europe only after the 1989/91 political upheavals. Because of its uneven development and different historical trajectories, the institutionalisation of political science in Europe is still a work in progress. There are strong political science communities in Western Europe, whereas the discipline remains weak in many Central and Eastern European countries.

Unfortunately, we still do not have a clear overall picture of the state of the discipline in the various European countries. This is due to several factors. As Martin J. Bull (2007) has noted, existing state-of-the-art studies are not based on sufficient comparable data. It is difficult to find even basic numerical indicators for comparison, such as the age, gender, and

\footnotetext{
E. Berndtson ( $\square)$

University of Helsinki, Helsinki, Finland

(C) The Author(s) 2022

G. Ilonszki, C. Roux (eds.), Opportunities and Challenges for New

and Peripheral Political Science Communities, https://doi.org/10.1007/978-3-030-79054-7_8
} 
international profiles of scholars or their areas of specialisation. ${ }^{1}$ Most studies focus on single countries only, and European is too often understood from a parochial perspective. This does not facilitate an understanding of the discipline from a pan-European perspective. Among the few comparative studies (Stein, 1995; Boncourt, 2007, 2008; Klingemann, 2007a, 2008), only Hans-Dieter Klingemann's, 2008 article attempts to cover all European countries. The situation is partly the result of a language problem. For better or for worse, English has become the new lingua franca in political science. Many studies written in other languages remain unknown to the wider political science community. Furthermore, the current pace of change of higher education systems is so rapid that many country reports on the state of political science are already out of date by the time they get published.

Recognising these difficulties does not mean that we cannot try to build a coherent picture of European political science. As Hans-Dieter Klingemann has remarked, "if we do not want to just add another lamento we need to have courage to start somewhere" (Klingemann, 2007a, p. 18). The present article follows the same line of reasoning. Going beyond single-country studies, this article analyses the institutionalisation of political science as a discipline from the perspective of European political science organisations. In doing so, it pays special attention to the Central and Eastern European countries, as these are still under-represented in European political science cooperation frameworks.

The concept of European political science needs to be clarified here. It is important to understand the difference between political science in Europe on the one hand, and European political science on the other. European political science differs, for example, from American or Japanese political science (cf. Brintnall, 2004, p. 2), since Europe is not a single nation but consists of different political science communities, each with its own methodological approaches and research interests (although some countries are intellectually closer than others). Different individual country studies present a view of political science in Europe. European political science, on the other hand, refers to the collective action of political science communities interacting with one another within a common framework.

${ }^{1}$ The COST project PROSEPS "Professionalization and Social Impact of European Political Science" (https://proseps.unibo.it/, accessed June 15, 2020) is, in fact, the first systematic attempt to collect data for the purposes of these indicators. 
The easiest way to define European political science would be as a "geographically circumscribed discipline" (Bull, 2007). However, a simple geographical definition is problematic, as it does not take into account the political and cultural context of the discipline. Thus, it may be a good idea to adopt Hans-Dieter Klingemann's suggestion that European political science could be defined by using the European Higher Education Area (EHEA) as a criterion (Klingemann, 2008, p. 370). To be a member of the EHEA, a country must be a party to the European Cultural Convention, and must pursue the objectives of the Bologna Process within its higher education system. This means that contemporary European political science is a "Bologna circumscribed discipline". European-level higher education policies bring separate political science communities together, as these policies frame the conditions for research and teaching. As Hans-Dieter Klingemann has noted, "[ $t]$ he political effort to harmonize Europe's higher education has deeply affected all academic disciplines" (Klingemann, 2007a, p. 15). This development requires European political scientists to work together.

Using this criterion, the European academic community can be considered as comprising forty-eight national systems, including those of Armenia, Azerbaijan, Georgia, and Kazakhstan. If we add a further two countries that are not party to the Bologna Process-Monaco and San Marino-we get a grand total of fifty countries. However, Monaco and San Marino, just like the other European micro-states (Andorra, the Vatican State, and Liechtenstein), do not offer political science programmes in their higher education institutions. Consequently, as things stand, we can narrow European political science down to forty-five countries.

These forty-five political science communities represent different levels of institutionalisation. At the general level, the institutionalisation of a discipline requires specific structures by means of which a discipline's intellectual products are disseminated, its standards maintained, and new recruits introduced to its practices. These structures include departments, undergraduate and graduate programmes, journals, scholarly societies, and the 'invisible college' of colleagues working on related problems and theories (Cairns, 1975, p. 203). As the theoretical chapter of the present volume argues, an ideal type of a fully institutionalised discipline refers to its stable and legitimate structures with means to maintain and strengthen them. The discipline should also have a clear identity and autonomy in relation to other disciplines. In addition, the institutionalisation of the 
discipline requires that it must be recognised internationally. As the chapters in this book show, the degree of institutionalisation of political science varies from one European country to another.

When political science was institutionalised as a discipline in Western Europe, it was helped by international organisations such as the International Political Science Association (IPSA) and the European Consortium for Political Research (ECPR). ${ }^{2}$ As Martin Bull points out, " $\mathrm{t}$ ]o exist as a community, European political science should be characterized by cross-national interactions and communication through European journals and other media, and it should have cross-national organisations which promote and facilitate these interactions" (Bull, 2007, p. 430). In that respect, international associations have a major role to play. At the national level, they lend legitimacy to a given discipline. At the international level, they offer a common platform for scientific activities. It would seem, however, that European cross-national organisations do not currently promote and facilitate European political science successfully. Resolving this problem is vital if European political science is to develop more fully.

\section{The Institutionalisation of Political Science in Western Europe: The Role of International Political Science Organisations}

In order to discuss international cooperation in the field of political science, UNESCO organised a conference on research methods in September 1948 in Paris. A declaration made after the conference stated that it is natural and justified for political science to evolve within national frameworks, as historical traditions, educational structures, philosophical concepts, political systems, and social structures mould the discipline (see Coakley \& Trent, 2000, p. 16). The aim of cooperation is not to put an end to the intellectual diversity of the study of national subjects, or to the variety of methods (juridical, historical, philosophical, sociological, psychological, and statistical) employed, to be replaced by a single conception of political science (Coakley \& Trent, 2000, pp. 14-8). However, it was

\footnotetext{
${ }^{2}$ This has also been noticed in Central and Eastern Europe. For instance, one Hungarian scholar, Attila Ágh, has pointed out in regard to Hungary, that "[i]n the professionalization of Hungarian political science, international institutionalization, such as contacts with IPSA, APSA and ECPR, can play a dominant role" (Ágh, 1995, p. 214).
} 
seen as necessary to learn from others in order to broaden one's horizon, to facilitate mutual understanding, and to avoid isolation and prejudice.

The conference led to a report consisting of forty-nine articles describing the state of political science around the world (UNESCO, 1950). In the Introduction to the report, Massimo Salvadori identified five existing national traditions in the study of politics, "[a] national criterion, adopted on the basis of the material assembled in this volume, would perhaps enable us to distinguish five main types of political science. These are in alphabetical order, the American, British, French, German and Soviet Schools of thought" (Salvadori, 1950, p. 9; see also Coakley \& Trent, 2000 , pp. 3-4).

John Coakley (2004, p. 172) has further elaborated these types. The American approach was characterised by an openness to methodologies from the other social sciences. The British approach had been embedded in moral philosophy, but had slowly started to assert its independence. The French approach was rooted in the Roman law tradition, while the German approach had originated in constitutional and administrative law and evolved into a systematic study of the state. The Soviet approach, on the other hand, was based on Marxism-Leninism.

There were two main questions dividing these traditions and reflecting their different intellectual roots: (1) can politics be studied as a separate field of research?; and (2) can politics be studied scientifically, that is, using the same methods adopted in the natural sciences? The American approach emphasised the scientific study of politics as an independent discipline, and it also believed in the possibility of using rigorous methods to study social phenomena.

British scholars in particular were sceptical about both of the aforesaid goals. British authors emphasised that "[i]n political theory we must give a prominent place to the history of political ideas" (Robson, 1950, p. 294) and "nearly all English thinkers are agreed that you cannot understand any system of government or, indeed, any political idea, without knowing its historical background, origin, and growth" (Robson, 1950, p. 306). The British understanding of the study of politics is also clear from the decision to call the British association the Political Studies Association, and not the Political Science Association (Grant, 2010, pp. 16-23).

French scholars agreed with their British counterparts "that political science can be studied only in the larger framework of the social sciences" (Salvadori, 1950, p. 8), albeit for different reasons. Lazare Kopelmanas pointed out that the term "political science" was familiar to scholars in the 
English-speaking world, but did not refer to a clearly defined scientific discipline in France, where the study of politics was seen as part of "political sciences", since "practically all of the social sciences could be qualified, at least in certain aspects, as political sciences" (Kopelmanas, 1950, pp. 647-8). Politics was not perceived as a separate discipline. On the other hand, political parties, public opinion and elections were often studied from a sociological perspective using empirical methods (Goguel, 1950 , p. 503). In addition, the French higher education system has been marked by its duality since 1945, that is, its division into universities and "Grande Ecoles" (see Blondiaux \& Déloye, 2007, p. 137). At French universities, the study of political science has been mainly assigned to the universities' law faculties, where in the late 1940s political institutions were viewed from a legal, rather than a sociological, perspective, albeit with certain important exceptions (Duverger, 1950, p. 370). The empirical study of politics was given freer rein at the country's Instituts d'Etudes Politiques (IEPs), the first seven of which were established in 1945 as interdisciplinary social science institutions.

German scholars were also divided on the two issues. The old German Staatslehre tradition had been discredited after the War, and the German study of politics was a highly fragmented discipline at the time. According to Klaus von Beyme, it consisted of four main schools: (1) the normative school of Freiburg, which extended to Munich; (2) the early mainstream school of political science established by traditional liberal institutionalists; (3) the method-conscious behaviourists concentrated in Cologne and Mannheim; and (4) political scientists of a Marxist persuasion (Beyme, 1982 , p. 170). Given that some of the returning émigré scholars introduced the ideas of American political science into Germany, this rendered part of German political science responsive to the idea of the scientific study of politics, especially among method-conscious behaviourists. Such ideas also favoured the establishment of political science as an independent discipline.

The Soviet approach differed in many ways from the Western approaches. In principle, it could accept the idea of the scientific study of politics (from the perspective of historical materialism). What it could not accept, however, was that political science constitutes an independent academic discipline, for the simple reason that Marxism-Leninism already accounted for the workings of politics.

The four different European approaches to political science reflected the state of the study of politics in Europe after the Second World War. It 
was also assumed that other European countries were followers of these intellectual traditions. It is important to understand the initial state of the study of politics in Europe, as seventy years ago there was no political science discipline as we now understand it. However, the project concerning methods in political science led to the founding of the International Political Science Association (IPSA) in 1949, which then played a major role in the institutionalisation of the discipline. American political scientists were key players in this process (together with European scholars who went to stay in American universities as visiting scholars (Daalder, ed., 1997), hence the introduction of the "American approach" in Europe.

The establishment of the IPSA has been vital for the development of political science as a separate academic discipline. Without the IPSA, the European study of politics could have remained rooted to national traditions for a considerable time longer. The International Political Science Association's foundation also required national political science associations to be set up in Europe (Boncourt, 2009). It is important to remember that the IPSA came first, with most national associations established some time thereafter. ${ }^{3}$ This development then facilitated the establishment of separate political science departments in European universities. In the 1950s, political science began to be established as a discipline in the major nations in Western Europe (France, Germany, UK), in the Nordic Countries (Denmark, Finland, Norway, Sweden), and in the two Benelux countries (Belgium, the Netherlands). However, even in these countries, its legitimacy was often questioned. For a number of reasons, this development was not as rapid in Italy (for cultural and political reasons), ${ }^{4}$ Ireland

\footnotetext{
${ }^{3}$ At the time of the 1948 UNESCO conference on the study of methods, there were only four national associations in existence: the American Political Science Association (founded in 1903), The Canadian Association (1912), the Finnish Association (1935), and the Indian one (1938). When the IPSA Constitution was drafted, it was decided that it would come into effect only when at least four national associations had joined the organisation as collective members. As the Finnish Association was not interested in becoming a member at that time, one more association was needed. Accordingly, the 1949 founded French Association became the fourth founder member of the IPSA. Other national associations were then to follow (UK 1949, The Netherlands 1950, Belgium 1951, Germany 1951; see Table 8.1).

4 "In post-World War II Italy... Marxists, old Liberals, and Catholics inspired by the social doctrine of the Church, dominated the stage, and were equally suspicious of empirical disciplines such as political science", and "The anti-political science academic component was a tri-partite coalition of axiological philosophers, Kelsenian law professors and historians preaching neo-idealistic historicism" (Freddi \& Giannetti, 2007, p. 257).
} 
(for cultural reasons), ${ }^{5}$ or Austria and Switzerland (because of the dominance of law), although political science gained ground in these countries as well during the course of the 1960s. Its delayed emergence in Switzerland has been accounted for as follows: "[i]t was considered unacceptable that politics which was everybody's affair would become that of a few specialists... and $[\mathrm{u}]$ ntil very recently, law was considered a discipline both necessary and sufficient for a good understanding of Swiss politics" (Wemegah, 1982 , p. 327).

Furthermore, the development of political science as a separate academic discipline was halted in Greece, Portugal, and Spain due to the authoritarian political systems in place in those countries up until the mid/ late 1970s. On the other hand, in the cases of Iceland, Cyprus, Luxembourg, and Malta, the late development of political science in these countries can be partly accounted for by the delayed development and the limited entity of the higher education sector itself(e.g. Agapiou-Josephides, 2007 , p. 78 ). In Iceland, the first university was founded in 1911, in Cyprus in 1990, and in Luxembourg in 2003. All of them now have their own political science departments. The one exception is the University of Malta, which was founded in the sixteenth century, but has no political science department to date (although there are departments of public policy and international relations).

Following the recognition of political science as a clearly identifiable discipline in Western Europe, its development continued with the founding of the European Consortium for Political Research (ECPR) in 1970. This would not have been possible without the initial impetus offered by the IPSA, with its idea of political science as an independent academic discipline. The setting up of national political science associations also strengthened the position of the universities' political science departments.

The backbone of the ECPR was represented by the universities in those countries where political science had developed during the 1950s and 1960s. ${ }^{6}$ The ECPR offered political scientists (as department members) a new platform for cooperation. A good example of this is that of Nordic countries. Scholars had been cooperating unofficially since 1964, which

\footnotetext{
${ }^{5}$ Although the first Politics chair was founded already in 1908 at the University College, "[p]olitical science remained underdeveloped as a university subject during the inter-war years", as "the college's origins as a Catholic university long remained visible" and "areas considered 'sensitive' by the Catholic church (such as education, philosophy and politics) were especially prone to clerical influence” (Coakley \& Laver, 2007, p. 244).

${ }^{6}$ The ECPR's membership is based on institutions.
} 
had led to the first Nordic political science conference being held in 1966, and to the launching of the yearbook Scandinavian Political Studies that same year. After the establishment of the ECPR, it was felt that cooperation should be based on more solid foundations. In 1975, the Nordic Political Science Association (NOPSA), composed of the national political science associations of Denmark, Finland, Iceland, Norway, and Sweden, was founded. One of its objectives was the coordination of the Nordic countries' activities in the IPSA and the ECPR.

The ECPR has been instrumental in the development of the discipline also in those Western European countries where political science was a latecomer. ${ }^{7}$ Italian and later Spanish universities, in particular, took a keen interest in the ECPR's work. While the IPSA had introduced American political science to Europeans, during its early development, the ECPR also adopted the American model (see Blondel, 1997, pp. 116-7). As to the impact of the American model in Europe, Hans-Dieter Klingemann (2007a, p. 14) points to the argument put forward by Ken Newton and Joseph Vallès, whereby " $[\mathrm{t}]$ o take up the behavioural approach in the 1960s and the 1970s was to distinguish political science from law, philosophy, history and economics. This helped to build up independent departments of political science in the universities" (Newton \& Vallès, 1991, p. 236).

The main purpose of the ECPR was initially to enhance Europe-wide comparative and empirical research. The Consortium began with eight members in 1970. In the intervening fifty years, it has grown into an organisation with over 300 members. ${ }^{8}$ As its membership has increased, the Consortium has become more open to different philosophical and theoretical traditions. ${ }^{9}$ The nature of the ECPR has also changed. In its activities, it emphasises scientific standards and practices which have

${ }^{7}$ The ECPR did not accept members from socialist countries, because political science could not be conducted freely in those countries. Its policy differed from that of the IPSA which encouraged Central and Eastern European political scientists to participate in its activities, in the belief that this was a way of introducing Western political science into these countries.

${ }^{8}$ In June, 2020, the ECPR had 270 European members (out of a total of 317 members, the remaining forty-seven being non-European members; https://ecpr.eu, accessed June $10,2020)$.

${ }^{9}$ To the extent that a number of European political scientists, favouring quantitative research methods and formal modelling, decided to establish the European Political Science Association (EPSA) as a form of protest in 2010 (Boncourt, 2017). 
developed within Western academia during the last thirty years (peer reviews, the impact of journals, high-quality workshops, cooperation with the best universities in the world, the awarding of prizes to outstanding researchers, a Code of Conduct, and a Gender Equality Plan). All of these are of course worthy principles. However, they may not leave much room for political scientists with less experience in Western (often AngloAmerican) social science practices to participate in the ECPR's activities.

\section{Indicators of the State of Political SCIENCE In Europe}

The early history of European political science helps to explain why political science is still dominated by West European countries. On the other hand, even in Western Europe, there are only two strong political science communities, namely the ones in Germany and in the UK. In order to create a truly European political science, it is important to analyse the reasons for this situation and to find ways of strengthening the discipline in those countries where political science has remained largely undeveloped.

The following table offers a concise summary of the development of political science in Europe and of its current state. Eight indicators offer background information for the analysis in the article. Together they describe the level of institutionalisation of political science, its strengths, stability, legitimacy, identity, autonomy, and internationalisation. The indicators are: 1) the year in which political science was first afforded a chair or a programme in a given country; 2 ) the current number of political scientists in a country; 3 ) the number of political science institutions in a country; 4) the number of ECPR members in a country; 5) the year a national political science association was founded; 6 )the number of members of a national political science association; 7) membership of the International Political Science Association (Yes/No); 8) membership of the European Confederation of Political Science Associations (Yes/No). ${ }^{10}$

\footnotetext{
${ }^{10}$ Information about the first political science chairs/recognised programmes is based on the country reports, prepared in the project "Professionalisation and Social Impact of European Political Science", PROSEPS (https://www.proseps.unibo.it, accessed June 15, 2020 ), and on the articles published in Klingemann, ed., (2007b). The number of political scientists is based on PROSEPS data (Action/Deliverables). The number of political science institutions is based on the PROSEPS country reports, except in the cases of Poland, Russia, Belarus, and Ukraine (in italics), where figures are based on Eisfeld and Pal, eds. (2010b). ECPR membership is based on the ECPR's website (https://ecpr.eu, accessed June 10,
} 
Table 8.1 gives a rough overall picture of the development and present state of political science in Europe. At the same time, it must be said that some of the figures are skewed. There are interpretative and conceptual problems concerning the nature of political science which often make it difficult to compare the state of the discipline in different countries. Political scientists differ in the ways they see the discipline, as is reflected in surveys regarding political science. One example is the year in which the first political science chairs/ programmes were established. If a university had a Professor of Politics in the seventeenth century (for instance, Swedes often refer to a professorship in eloquence and government at Uppsala University in 1622, as being the world's first professorship in political science), can that be counted as a Chair in Political Science? It would seem not, as a distinction has to be made between political science as an academic discipline and the study of politics in general. Politics has been studied, and can be studied, under different disciplinary labels, such as history, constitutional law, sociology, social policy, urban planning, and so on. Furthermore, the European roots of the study of politics can be traced back to ancient Greece (or indeed earlier), and politics has been taught at European universities since the Middle Ages (see Schüttemeyer, 2007, pp. 163-4), when it was studied as part of the courses in philosophy, constitutional law, and history.

In fact, political science as a separate academic discipline is in many ways an American invention, consisting of the idea of the scientific study of politics conducted within independent political science departments. What has given the study of politics special status in the United States (compared to Europe) is the institutional structure of American universities. One important innovation was the creation of a system of departments, compared to the traditional single-chair systems. These departments were interposed between individual professors and the university itself (Wittrock, 1985, p. 25). This offered more opportunity for the recognition of new disciplines, political science being one of them. Another important event was the founding of the American Political Science

2020). Information regarding the foundation of national political science associations and their membership is based on the PROSEPS country reports, Klingemann (2008, p. 378), and Eisfeld and Pal ((2010a), pp. 30-1). Figures for membership of the IPSA and the ECPSA have been gleaned from the associations' respective websites (https://www.ipsa.org/; https://www.ecpsa.org/, accessed April 29, 2020). 


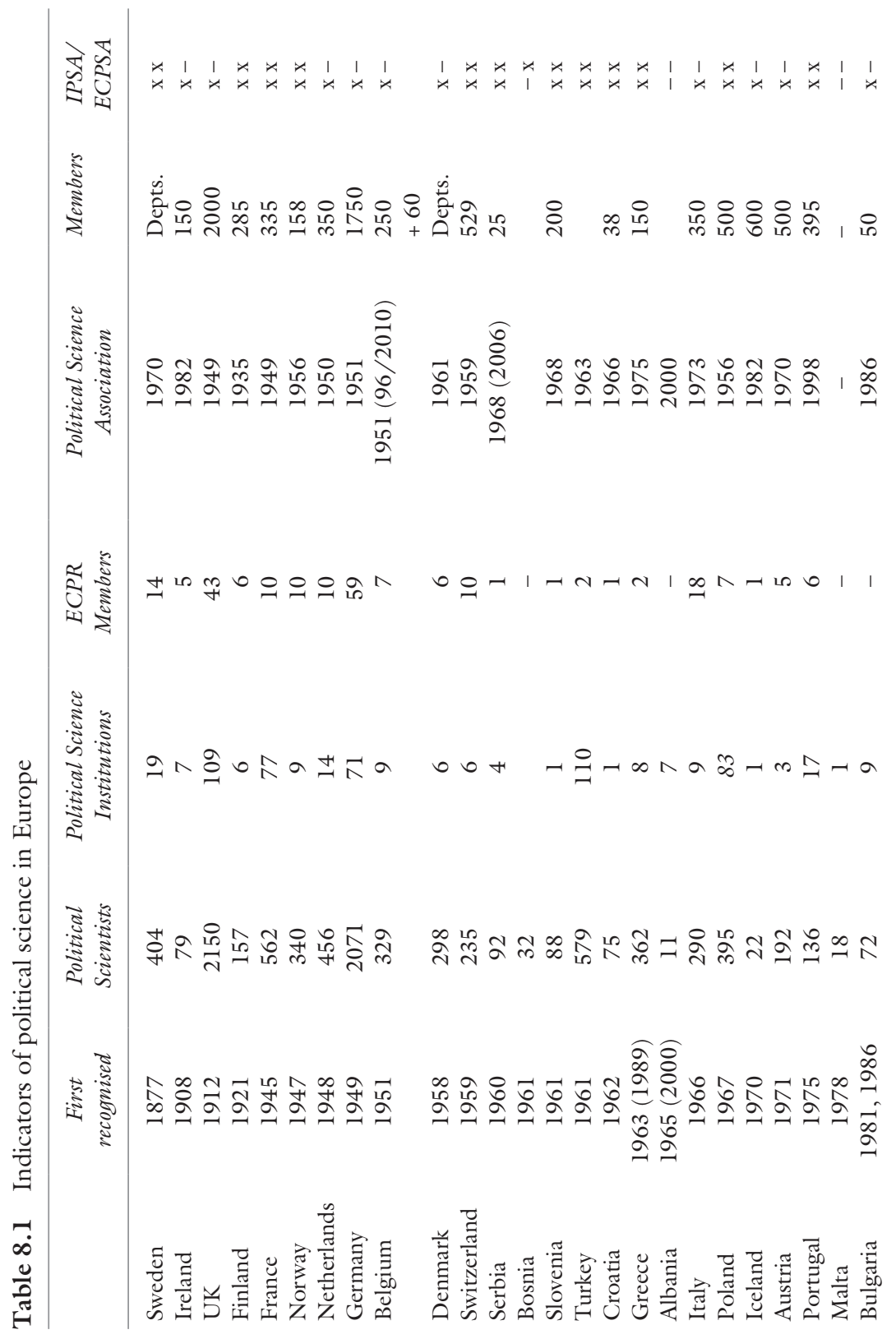




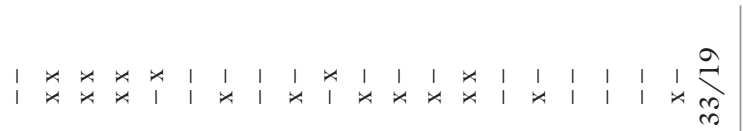

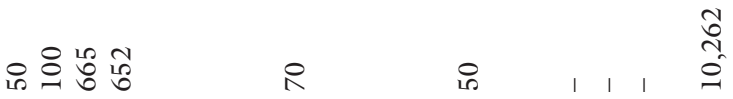

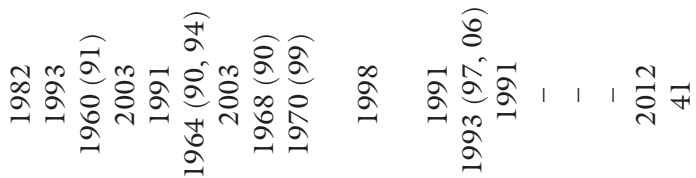

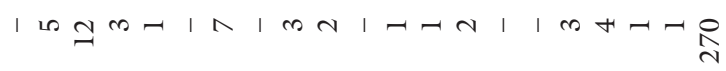

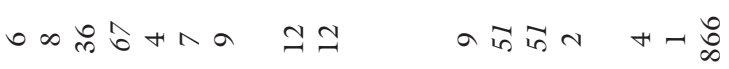

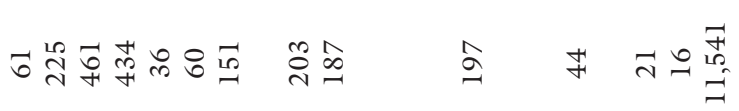

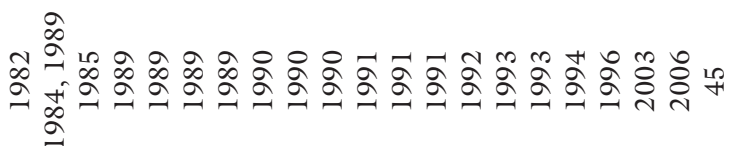

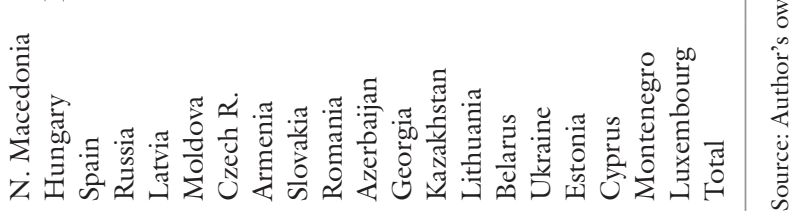


Association (APSA) in 1903, which offered political scientists a new identity. ${ }^{11}$

That would explain why, when the IPSA was founded in the late 1940s, the general opinion held in Europe was that "[p]olitical science, as a distinct branch from speculation concerning political phenomena or the history of these phenomena, is of fairly recent development, more recent, certainly, than other social sciences such as law, political economy and sociology" (Salvadori, 1950, p. 1).

The distinction between political science as a discipline and the study of politics in general is linked to the problem of subdisciplines. When political science began to develop in Europe following the Second World War, it was customary to include international politics and public administration as part of the discipline. When the International Political Science Association was founded in 1949, it was agreed that political science embraced four areas, namely: (1) political theory; (2) political institutions, including the public administration; (3) parties, groups, and public opinion; and (4) international relations (Coakley, 2004, p. 179). Today there are still some political science departments whose courses include the study of international relations and/or public administration; however, these fields can also be the concern of specific departments established for their teaching and research. This is particularly the case of many administrative science departments, which have completely cut their ties with political science. Moreover, there are some subjects which may be part of a political science department, but which often have their own dedicated departments (e.g. EU Studies). One new development has seen the creation of interdisciplinary units where political science is one subject among several others. This variety of institutional arrangements makes it difficult to count the exact number of departments and individual scholars concerned, especially when political scientists themselves perceive the discipline in several different ways. Although there are no simple solutions to these problems, it is important to acknowledge their existence when comparing political science in different countries. Ultimately, any comparison requires qualitative analysis.

${ }^{11}$ The idea of an autonomous research field is still the main factor determining political science's status as an academic discipline. The scientific study of facts is also a key factor, although nowadays "scientific study" does not necessarily equate to the imitation of the natural sciences. 


\section{The State of Political Science in Central AND EASTERn Europe}

Interpretative and conceptual problems are also evident when analysing political science in the Central and Eastern European (CEE) countries. Most political scientists agree that modern political science can only develop in a democratic environment, as the discipline is dependent on free scientific argumentation and communication among scholars. In authoritarian systems, it is difficult for political science to study politics in a critical manner (see, for example, Salvadori, 1950, pp. 8-9). This is one of the reasons why political science was not able to develop in the former socialist countries.

However, the relationship between political science and democracy is complicated. As David Easton, John G. Gunnell, and Michael B. Stein have argued, if we assume that democracy is a precondition for the existence of political science, how do we distinguish the effect of general social changes on the discipline from the specific effects of political regimes? Furthermore, how do we distinguish the effects of different aspects (institutions, operational rules, and ideologies) of diverse democratic regimes on political science? (Easton, Gunnell and Stein, 1995, pp. 8-9).

That is why certain elements of political science were also able to exist under socialist regimes, albeit in a limited or propagandistic manner. Political science had already been recognised as a discipline in the 1960s in the former Yugoslavia (Serbia 1960, Bosnia and Herzegovina 1961, Slovenia 1961, Croatia 1962), Albania 1965 and Poland 1967 (see Bibic, 1985; Wiatr, 1995).

Scholars were not free to study everything, but could still enjoy a certain intellectual autonomy. Poland is an interesting case, as the discipline of political science was established by the Communist Party mainly for propaganda reasons; however, at the same time, political sociology was able to develop more freely, and this was often critical of political conditions within Poland. Polish political sociologists were also able to cooperate with Western political scientists on international projects. For example, in the 1960s, Polish political sociologists (and Yugoslavian scholars) participated in the "International Studies of Values in Politics" project, together with Indian and American social scientists. It was "the first comparative empirical political research ever run in the Communist country" and "started a long series of the local power and government studies" (Tarkowski, 1987, p. 14). In that sense, political science did not start from 
scratch following the 1989/91 revolutions, given that CEE scholars had already had contacts with Western scholars before then, through the IPSA for example.

Political science can exist under authoritarian regimes, but is often compelled to narrow its scope. European socialist countries are not the only example of this phenomenon. For example, the study of politics was introduced at the Universidad Complutense de Madrid when Franco's regime was in place in the 1950s; however, the political science curriculum in that specific case was limited, and " $\mathrm{t}] \mathrm{o}$ avoid political controversy the dominant approach to the subject was legalistic and constitutionalist" (Etherington \& Morata, 2007, p. 325). The same tendencies can be seen today in existing authoritarian political systems. The PROSEPS country report on Russia states that as politics has become more authoritarian, "[s]ome universities close PS departments or merge them with Public Administration".

When political science began to develop in Central and East European countries in the 1990s, there were a number of problems to be solved concerning, among other things, higher education facilities and academic staff. Political science as a discipline had to gain legitimacy and compete with other disciplines for resources. In addition, during the socialist period, disciplines such as Scientific Communism were staffed by Marxist scholars. When some of these old disciplines changed their names to political science, the question of how to treat those people occupying old teaching and research positions, had to be asked. The present article is not the appropriate place for an analysis of the complex development of higher education policies in these countries. Suffice it to say that practices have varied from one country to the next. In some countries, Marxist scholars lost their jobs (e.g. in the former GDR), whereas in other countries they have managed to hold onto their posts (e.g. in Moldova).

The latest overview of the state of the discipline with a specific focus on Central and Eastern Europe, is already a decade old (Eisfeld and Pal, eds., $2010 \mathrm{~b}$ ), and it is evident that many things have changed since then. ${ }^{12}$ However, some factors hindering the development of political science, such as autocratic political tendencies, have persisted, and indeed have become even stronger (in Belarus, Russia, Moldova, and also Hungary

\footnotetext{
${ }^{12}$ More recent articles on political science in Central and Eastern Europe can be found in Krauz-Mozer, Kulakowska, Borowiec, Scigaj, eds., (2015b), which includes articles from twenty-seven Eastern and Western European countries. However, even this collection of articles is already partly outdated.
} 
and Poland). It seems that Eisfeld and Pal's (2010a, p. 25) conclusion that the "cohesion of the discipline and a high quality of research are lacking in almost half of the countries included here" remains valid. This does not mean that political science as a discipline has not developed in Central and Eastern Europe in recent years (see the country analyses in Krauz-Mozer, Kulakowska, Borowiec and Scigaj, eds., 2015b); however, even the editors of this book note that "[i]t seems that political science in Central and Eastern Europe still lacks a discussion of changes occurring in how we construct the criteria of scientificity, especially in relation to social sciences" (Krauz-Mozer, Kulakowska, Borowiec and Scigaj, 2015a, p. 11).

As argued in this article, in order to become fully institutionalised, an academic discipline must become an integral element of the international scientific community. This has been a problem for many universities and individual scholars in Central and Eastern Europe. It seems that only a few institutions participate fully in international cooperation. Even the Central European Political Science Association (CEPSA) founded in 1994 (and currently with eight member countries, namely: Austria, Croatia, Czech Republic, Hungary, Lithuania, Poland, Slovakia, and Slovenia), "does not seem to work as a very strong catalyst of Central/East European convergence" (Eisfeld and Pal, 2010a, p. 32). Much of political science research in Central and Eastern Europe is country-specific, and there seems to be little cooperation even between scholars with a shared historical background, such as those from the former Yugoslavia or Czechoslovakia (Jokic et al., 2019, p. 505).

The participation of Central and Eastern European political scientists in the conferences of the ECPR, the main pan-European political science organisation, also indicates that participation in international conferences is still rare or tends to be limited to scholars from just a few universities. There are only thirty-nine ECPR members from Central and Eastern European countries. ${ }^{13}$ This situation seems to reflect participation trends also at the individual level.

Table 8.2 gives information on participation at some of the most recent ECPR Conferences (General Conferences and Joint Sessions of Workshops). The conferences held in 2019 are the latest ones at the time of writing. Given that the General Conference was held in Wroclaw and the Joint

\footnotetext{
${ }^{13}$ However, some of the countries are well represented in the ECPR, especially the Czech Republic ( 7 members out of a total of 9 institutions, Hungary ( 5 members out of 8 institutions), and Estonia (2 institutions, but 3 members).
} 
Table 8.2 Participation in selected ECPR conferences

\begin{tabular}{llr}
\hline ECPR conferences & \multicolumn{1}{c}{ Participants } & From CEE \\
\hline General Conference, Canterbury 2001 & c. 1500 & 36 \\
General Conference, Oslo 2017 & c. $2500(2005)$ & 166 \\
General Conference, Wroclaw 2019 & c. $2400(1801)$ & 355 \\
Papers & & \\
Joint Sessions, Warsaw 2015 & $426(425)$ & 42 \\
Joint Sessions, Mons 2019 & $398(398)$ & 28 \\
\hline
\end{tabular}

Source: Author's counting of conference programmes (https://www.ecpr.eu/, accessed April 29, 2020)

Note: It must be pointed out, however, that the figures represent the participation of universities, and not the participation of Central and Eastern European scholars, as these may also be working for West European universities (and vice versa), there are Western scholars working at Central and Eastern European universities. The figures differ from the official figures (in parenthesis). This is due mainly to cancellations and no-shows. However, as the official statistics do not offer separate information on CEE participants, information taken from printed conference programmes is used instead

Sessions were held in Mons, for comparative reasons, the Oslo 2017 Conference and the Warsaw 2015 Joint Sessions were added to the Table together with the first ever General Conference held in Canterbury in 2001. That year, few of the Central and Eastern European scholars attended the General Conference. Oslo, on the other hand, is an expensive venue for a conference, which may account for the low levels of participation in 2017. However, one would have expected more Central and Eastern European participants to attend the 2019 Wroclaw Conference (112 of the 355 participants came from Polish universities it should be said).

The same trend can be seen also in regard to the Joint Sessions of Workshops. Furthermore, Western scholars act as important gatekeepers for the acceptance of who is to submit papers at a conference. In Warsaw, there were twenty-five workshops with forty-eight workshop directors and co-directors, forty-five of whom were from Western universities, and only three from Central and Eastern Europe. In Mons, there were fifty-one directors and co-directors, five of whom were from Central and Eastern European universities.

Low conference participation rates can probably be accounted for, in part, by the high ECPR Conference fees. ${ }^{14}$ The general tone in the

${ }^{14}$ Currently, the ECPR offers annual membership to Central and Eastern European institutions at half the price $(€ 1205)$ that Western European institutions pay ( $€ 2410$ ). Nevertheless, $€ 1205$ is still a high price for many CEE institutions. Furthermore, participation in conferences requires funds, which many Central and Eastern European scholars do not possess. 
PROSEPS country reports is that "resources for research are scarce" (Slovenia), "funding shortage has been a huge problem" (Poland), "the financial conditions are limited" (Bulgaria), and so on. The Lithuanian report states that "participation in conferences is required...Yet, rarely, institutions have funding, or if they have, these funds are not big". Language may also affect participation, as the ECPR only uses English in its activities. Older political science communities with more members also control the agenda of conferences, which may make it more difficult for scholars from new countries to get accepted as workshop directors or even as paper givers. Moreover, the research interests of Central and Eastern European political scientists do not always coincide with those of Western scholars (for example, according to the PROSEPS country reports, research fields such as social movements, gender politics, the political economy and, surprisingly, electoral behaviour, are not well represented on research agenda).

Participation in the ECPR's activities is only one indicator of course. However, it is easy to find other examples of the under-representation of Central and Eastern European scholars in European political science. ${ }^{15}$ In the study on articles published by CEE political scientists and indexed in the Scopus database during 1996-2013, it was found that the number of articles was almost negligible in 1996 and remained so up to 2006. After this there was an increase, but it was mainly due to the indexing of one Polish (2006) and two Lithuanian (2011) journals in the Scopus database (Jokic et al., 2019, p. 496).

CEE scholars are also under-represented in European funding schemes. Although Central and Eastern European universities have been able to participate in many programmes supporting internationalisation and academic mobility (EU funding, such as Erasmus and COST; Fulbright scholarships; bilateral agreements), most of these programmes are not directly linked to research. They foster networking among scholars and the adoption of foreign research models. These of course help to enhance research, but the problem is that they do not form any coherent platform for political science as a discipline. Although these schemes have helped

\footnotetext{
${ }^{15}$ Unfortunately, a study of all forms of international cooperation, such as publishing in international journals, degrees taken in foreign universities, finding permanent or temporary positions in foreign universities, research and teaching exchanges, participation in international projects, and research funding from international sources, is not possible within the context of this article.
} 
the development of political science, it seems that even the Bologna Process has been more important among Central and Eastern European political scientists with regard to disciplinary identity, than any of the aforesaid schemes.

Actual research funding would make a more important contribution towards the development of political science, but such funding often goes to Western scholars. An important indicator is the distribution of those grants awarded by the European Research Council (ERC). Between 2007 and 2019, the ERC distributed 235 Starting Grants in the panel "Institutions, Values, Beliefs and Behavior" (the panel representing sociology, social anthropology, political science, law, communication, and social studies of science and technology). ${ }^{16}$ However, only four such starting grants were given to young scholars from Central and Eastern Europe. The same trend can be seen also in regard to Consolidator and Advanced Grants. Between 2013 and 2019, of 96 Consolidator Grants awarded, none was given to Central and Eastern Europe. Between 2008 and 2018, of 103 Advanced Grants, only one went to a scholar in that part of Europe. ${ }^{17}$

The limited entity of research funding (and the low participation rates at international conferences) can be partly accounted for by the fact that many departments, especially in Eastern European countries, do not yet represent consolidated academic units. For instance, while there is a clear potential in Russia and Romania for the development of political science as an academic discipline, political obstacles and internal rivalries have hindered this development. If ECPR membership is used as an indicator of international orientation, then it should be pointed out that ten countries have no ECPR members at all (Armenia, Azerbaijan, Belarus, Kazakhstan, Moldova, Ukraine, Bosnia and Herzegovina, Montenegro, North Macedonia, and Albania). Although there is no direct link to EU membership, one could argue that the said membership seems to indirectly foster European cooperation within all social arenas, including that of political science.

Therefore, Central and Eastern European political science communities should not be treated as constituting a single block. Although this book

\footnotetext{
${ }^{16}$ As many grants were given to interdisciplinary projects, it is difficult to say how many political scientists were involved.

${ }^{17}$ The information about ERC funding can be found at ERC's website (https://erc. europa.eu/projects-figures/statistics, accessed April 29, 2020).
} 
and the chapters within follow a somewhat different design (see Chap. 1), there are grounds for dividing them into at least five separate groups (cf. Eisfeld and Pal, 2010a, p. 25):

1. The former Soviet Union (Russia, Belarus, Ukraine, Moldova, Armenia, Georgia, Azerbaijan, and Kazakhstan)

2. The Baltic Countries (Estonia, Latvia, and Lithuania)

3. The Central European Countries (Poland, the Czech Republic, Slovakia, and Hungary)

4. The Former Yugoslavia (Slovenia, Croatia, Serbia, BosniaHerzegovina, Montenegro, and North Macedonia)

5. The other Balkan Countries (Albania, Bulgaria, and Romania).

Although there are differences within the aforementioned groups, it may be argued that political science has been developed to the greatest degree in the Baltic countries (especially Estonia and Lithuania), in the Central European countries (Poland, the Czech Republic, Hungary), and in some of the former Yugoslavian states (Slovenia and Croatia). In that sense, the situation of political science in Central and Eastern Europe is not as grey as it may seem. However, the under-representation of CEE countries in European political science remains a problem. There is no simple explanation for this situation. How political science will develop in these countries depends very much on country-specific factors such as the structure of universities, intellectual traditions, available resources, and the political climate. On the other hand, it is important to note that outside support is sadly missing at present.

\section{The Fragmented Field as an Obstacle to the Adaptation of New Countries to the Existing (Old) Institutional Frameworks}

During its development in Western Europe, political science was coordinated and strengthened by the IPSA and the ECPR. There were political reasons for this. The IPSA was initiated by Americans in order to strengthen democracy and bolster America's global influence following the Second World War. The ECPR, on the other hand, was established by West European scholars who wanted to make empirical research more rigorous, along the lines of American behaviouralism. While one may disagree with 
the motives of the founders of the IPSA and the ECPR, this is of little relevance from the current perspective. History has always produced unintended consequences. Contemporary political science is a methodologically and theoretically open academic discipline. In order for this to happen, political science needed the IPSA's and ECPR's endeavours.

The problem is that the IPSA and the ECPR have failed to respond to current-day demands. From a European perspective, the ECPR should have been a key player of course. It should have paid greater attention to the problems of political science in Central and Eastern Europe. It should have more clearly acknowledged the fact that higher education has become market-oriented and that there is now increased competition between universities as they each attempt to raise their ranking. Furthermore, it should have focused more on the European Commission's growing interest in higher education and research following the signing of the Maastricht Treaty in 1992, which influenced member states' national agendas (Goldsmith \& Berndtson, 2002).

As the ECPR failed to take the initiative in these matters, two new panEuropean political science associations have tried to address the problems of the changing academic context: the Thematic Network in Political Science (TN, 1997-2001)/ European Political Science Network (epsNet), (2001-2009); and the European Confederation of Political Science Associations (ECPSA, 2007-). The first of the two to enter the field was the Thematic Network in Political Science, which was set up in 1997 with funding from the European Commission, and was coordinated by Sciences Po in Paris. It was a result of the Commission's interest in furthering cooperation between European scholars (Thematic Network Action under the Socrates Programme), and the interest of some French political scientists (mainly in Sciences Po) to make the French discipline more outwardlooking (Topf, 2007). In the beginning, its main focus was on Western European political science. The starting point was a conference on "The State of Political Science in Europe" held in Paris in April 1996. All participants were from Western Europe, and they presented papers about the state of political science in their respective countries (Quermonne, dir., 1996). It was after this conference that the Thematic Network was founded.

However, there was considerable opposition to the setting up of the Thematic Network, as many political scientists in the countries where the discipline was already well-established were satisfied with the ECPR, and felt that the Thematic Network was an unnecessary complication. Several 
attempts were made to establish a working relationship between the two organisations. It was proposed that the ECPR (initially modelled on the Inter-University Consortium for Political and Social Research, Ann Arbor, 1962-) should carry on with research and research training, as before. The Thematic Network, on the other hand, would concentrate more on matters of teaching, professional development and lobbying of the European Union. Although this division of labour would have made sense, as the ECPR had not done much with regard to teaching and was not interested in lobbying, relations between the organisations remained lukewarm.

The Commission's funding for the Thematic Network was for four years only. After this, the network was expected to be transformed into a permanent association, if it wanted to continue operating as an organisation. There was a consensus among those who had worked in the TN and on its projects, that there was a need for a new European political science association designed to address problems which the ECPR had avoided tackling. Accordingly, the European Political Science Network (epsNet) was founded in 2001 to continue the TN's work. ${ }^{18}$ At the same time, the epsNet began to take an interest in European political science as a whole, with its president, Hans-Dieter Klingemann, taking on the task of getting Central and Eastern European political scientists to join the network. Annual conferences, for instance, were regularly held in Central Europe (Krakow 2002, Prague 2004, and Budapest 2006).

However, the epsNet's problem was that it lacked funding. Following its establishment, it managed to continue the work of the old Thematic Network, thanks to additional fundings for its projects from the European Union. However, this funding ended in 2005, after which the organisation had to be financed by other means. It was hoped that the epsNet could attract more members and solve its financial problems partly through membership fees. To this end, it adopted a system of collective membership (departments), individual membership, doctoral membership, and associate membership (mainly scientific associations). In order to attract

\footnotetext{
${ }^{18}$ The epsNet was established as a scientific association under French law. According to its Constitution (epsNet 2001), its objectives were: to promote cooperation in the teaching of political science; to enhance the visibility of the discipline and the profession; together with political science associations and other organisations, to provide a forum for the discussion of issues relating to the discipline; to provide a periodic review of the discipline; to strengthen the links between the academic community and the labour market; to stimulate the exchange and mobility of staff and students; to provide members with information on the profession; and to offer specific services to members.
} 
more members, membership fees were kept low or even waived (in the case of doctoral students and associations) so that a lot more people would be encouraged to join. Departments already paid high ECPR fees, and it was felt that collective members were not willing to fund epsNet, accordingly. Moreover, as one of the epsNet's key goals was to attract more scholars from Central and Eastern Europe, it was acknowledged that departments and individual scholars in these countries could not afford high membership fees, hence the reduced fees.

The strategy proved unsuccessful, however, and membership numbers remained low. In June 2003, (epsNet, 2003), there were thirty-eight collective members from West European universities and eleven from Central and Eastern Europe. There were also fifty-nine individual members from Western Europe and fifty-one from Central and Eastern Europe. An interesting thing was that the epsNet was able to attract more individual doctoral students in Central and Eastern Europe (56) than in the West (34). Considering all membership categories, while France had the most members (41), it was followed by three Central and Eastern European nationsPoland (32), Hungary (24) and Slovakia (20)_ _ahead of Germany (16) and the UK (14) (espNet 2003). ${ }^{19}$ This indicates that the epsNet was able, to a certain degree at least, to appeal to scholars in Central and Eastern Europe.

However, despite the fact that the TN and the epsNet had run a number of projects (e.g. state of the discipline; political science in Europe after Bologna; doctoral studies in Europe; EU virtual learning; training workshops for young university teachers), had organised yearly conferences, published research reports and a net-journal, their activities gradually began to wane. In 2009, the epsNet joined the ECPR, becoming one of the latter organisation's networks. This did not alter the situation, however, and although epsNet has never been officially dissolved, it has not conducted any activities since joining the ECPR. ${ }^{20}$

The short (unsuccessful) history of the epsNet is more complicated however, since financial reasons were not the only factors leading to the network's demise. Poor administrative decisions and inter-personal

\footnotetext{
${ }^{19}$ Athough the figures seem low, it should be said that when staff of collective members were taken into account, the epsNet's membership comprised around 1000 individual scholars.

${ }^{20}$ The epsNet has only had one direct effect on the ECPR. In 2011, a few people who had previously been active in the epsNet's governance, set up a Teaching and Learning Politics standing group for the ECPR. Theirs was a private endeavour, however.
} 
problems also contributed to this outcome. This is why some of the members of the epsNet's last Executive Council began to organise cooperation between national political science associations in Europe. The idea of establishing an "Association of European Political Science Associations" was already being mooted in 1998. Concrete proposals were also made as to how this could be done, and a number of informal meetings of representatives from national political science associations were held to discuss the state of European political science (Furlong, 2007). It was not until 2007 however, that this cooperative idea was put into practice with the founding of the European Confederation of Political Science Associations. This Confederation now boasts nineteen members (see Table 8.1), but it still appears beset by the same problems that the epsNet had. It has tried to organise a number of projects, but they have failed to be completed. It is interesting that the International Political Science Association (IPSA) seems to attract more European members than the ECPSA (see Table 8.1), despite the ECPSA's very low membership fees. ${ }^{21}$

The establishment of the epsNet and the ECPSA reveals the need to do something about the organisational structure of European political science. This has turned out to be difficult to achieve, however. ${ }^{22}$ Even the ECPR has not developed as well as it should have; its membership has tended to remain stationary for several years, and indeed has even declined in certain countries. Furthermore, the ECPR's 270 European members represent only a minority of all political science institutions in Europe. ${ }^{23}$

${ }^{21}$ See the ECPSA's website (http://www.ecpsa.org/index.php/publications/8-basicpage/18-standing-orders).

${ }^{22}$ In addition, the European Political Science Association divides European political scientists further and hinders the overall development of the discipline. It must be noted that EPSA's membership consists mainly of West European and American scholars. In 2013, their share of members was $96.5 \%$, while the share of Central and Eastern European scholars was $1.3 \%$ (Boncourt, 2017, p. 22).

${ }^{23}$ See Table 8.1. According to the PROSEPS country reports, there are at least 614 political science institutions in Europe, of which 519 are in Western Europe and 95 in Central and Eastern Europe. However, the data are missing for Azerbaijan, Armenia, Belarus, Bosnia, Georgia, Kazakhstan, Poland, Russia, Belarus, and Ukraine. If the data from Eisfeld and Pal, eds., (2010b) concerning Poland (83 institutions), Russia (67), Belarus (51), and Ukraine (51) are added, the number of European political science units rises already to 866. It is, of course, difficult to say how comparable the data are. As noted earlier, it is challenging to compare political science units because there are large independent departments as well as different kinds of social science (or law) units, where political science has only a minor position. 
West European membership has developed unevenly, with 157 members from the UK, Germany, the Nordic and Benelux countries, representing over half of its European membership. This means that the countries where political science began to develop under the IPSA, and was strengthened by the founding of the ECPR, remain the Consortium's core nations.

European scholarly associations should enhance the development of political science, making it a fully institutionalised European political science. However, the problem is that the epsNet has ceased to exist and the ECPSA is not functioning particularly well, while the ECPR is still dominated by Western political scientists and is not ready to make any major changes to its activities. Furthermore, the EPSA is mainly a Western European/American organisation. The current field of European political science is organisationally fragmented, which makes it difficult to enable new countries to adapt to existing institutional frameworks, and to create an institutionalised pan-European political science discipline. New measures are needed to resolve this problem.

\section{Is it Possible to Identify a Common Interest of European Political Science?}

In spite of the under-representation of Central and Eastern European political scientists in European-level cooperative schemes, there are clear signs that they are interested in participating to a greater extent (McGrath, 2008). The now defunct epsNet is a good example of this. The division between West and Central-East European political science is also not evident in the ECPSA, since of its current nineteen members, nine are from West European countries and ten from Central and Eastern Europe.

As Thibaud Boncourt (2017) has argued, the emergence of European scientific associations (including those pertaining to political science) can be best explained by looking at the competing interests (in terms of scientific paradigms and academic institutions) of the key players behind the establishment of these associations. As noted above, this is evident in the cases of the IPSA and the ECPR. However, although different interests always affect behaviour, sometimes the establishment of scholarly organisations drives from the pursuit of common interests. The important question is: does European political science currently share a common interest?

In the 1990s, European political scientists began to discuss new strategies for European political science, as it was felt that something had to be 
done given the new political situation. One of the proposals made was to establish a new European Political Science Association. ${ }^{24}$ On November 28, 1998, the ECPR and the Thematic Network in Political Science organised a meeting in Paris with selected members of national associations and university departments. Before the meeting, a policy paper was distributed for discussion, and was signed by the then Chair of the ECPR Executive, Mogens Pedersen, and the Co-ordinator of the Thematic Network in Political Science, Gerard Grunberg (Pedersen \& Grunberg, 1998). The paper recognised the fact that, "at present there is no European political science organisation in the sense of the American Political Science Association". It was felt that there was "a clear need for a European body that looks simultaneously at teaching issues, research and professional matters", and that there was a need to transform existing organisations into one European-wide organisation, "a European body that looks at teaching issues, curricula, standard qualifications, credit transfer etc." Although the meeting did not come to any decisions, its communiqué stated that, "[ $\mathrm{t}]$ he meeting concluded that the existing organizational structure is in need of thorough discussion by all European political scientists".

As the policy paper pointed out, European issues and European integration demanded greater attention; for example, universities needed to be more aware of the job market's demand for their students. Moreover, European Commission funding of research, teaching and mobility was on the increase and a single pan-European organisation would more likely attract such funds for the development of European political science. It was also felt that a single association would give the profession a higher profile in Europe, and would be a worthy partner for both the APSA and the IPSA.

Nonetheless, this initiative failed to bring about any changes. One of the reasons for this was that there was strong opposition within the ECPR to the establishment of a new organisation. Consequently, it may be overly optimistic to think that a completely new European political science organisation could be created in order to replace the existing organisations. Over the last two decades, various attempts to render European political science more cooperative and efficient have shown that relations between scholars and organisations are complicated when it comes to establishing political science policy. Europe is still too heterogeneous an

\footnotetext{
${ }^{24}$ As it has been noted, the EPSA has now been founded, but for different reasons.
} 
entity, characterised by too many competing interests. If something new is to be created, it should be based on the existing organisations.

Given that the ECPR is the leading European political science organisation, it should rethink its role and take greater responsibility for leading European political science in a new direction. It should adopt a more prominent role in regard to teaching issues (instead of having only one standing group devoted to such), and in representing the profession at the European level. More importantly still, it should pay greater attention to Central and Eastern European countries and try to get them involved in European cooperation. One small first step could be that of making the editorial boards of the ECPR's journals more representative (see Table 8.3).

It is hard to comprehend why Central and Eastern European scholars are so vastly under-represented on the editorial boards of these journals. Thirty-eight US scholars and an additional thirty scholars from other countries outside of Europe are members of these boards. One would think that having a more balanced European representation would broaden the journals' vision, and at the same time would help the ECPR become a truly European organisation. As was pointed out earlier, the ECPR has not managed to increase its membership in recent years, despite the fact that there are some 600 European institutions that could become members, but have failed to do so to date. The problem is that the ECPR

Table 8.3 Editorial boards of the ECPR's journals

\begin{tabular}{lcc}
\hline Editorial board & Members & CEE members \\
\hline European Journal of Political Research & 24 & 2 \\
Political Data Yearbook & 32 & 3 \\
European Political Science & 18 & 1 \\
European Political Science Review & 30 & 1 \\
European Journal of International Relations & 62 & 3 \\
Political Research Exchange & 21 & 2 \\
Total & 187 & 12 \\
\hline
\end{tabular}

Source: Author's own counting from the ECPR's website (https://www.ecpr.eu/), accessed, June 15,2020

Note: The Political Data Yearbook includes members of the International Advisory Board and the Editorial Board, the European Journal of International Relations includes members of the Editorial Committee and the International Advisory Board, the Political Research Exchange includes Associate Editors and Editorial Advisory Board 
appears to have become an academic business corporation advocating the ideology of the current market-oriented academia. It would do well to regain some of that early spirit it had aimed at expanding the realm of political science in Europe (see Rose, 1990).

At the same time, one important question remains, namely "[h]ow do different local political sciences diffuse and influence each other?" (Brintnall, 2004, p. 2). This is an important question, and concerns power relations within a potential single European political science organisation. Dominant political science communities influence weaker ones more than vice versa. A single European political science organisation could lead to the further strengthening of these power relations. Furthermore, a single organisation would probably lead to the English language becoming even more dominant in scientific communication. However, although the question of power is an important one, at the same time it is legitimate to ask what the alternatives may be. Power can also be power-to or power-with, rather than just power-over. It is up to political scientists as scholars to decide whether they are advancing their own interests (cf. Boncourt, 2017) or they are acting for the common good.

One solution would be to get the ECPR and the ECPSA to acknowledge that they need each other. The first step would be to strengthen the role of the ECPSA, since as an organisation it is currently weak and not a particularly appealing prospective partner for the ECPR. The problem is that most national associations are in fact weak (see Table 8.1), and fail to contribute very much to the work of the ECPSA. However, it would be easy to implement simple measures to make the ECPSA more relevant to the European political science community. Firstly, the ECPSA could operate mainly as a clearing house, divulging information about European political science. Each national association, on the other hand, could offer its services, insofar as possible, to other related associations. This would offer European political scientists a better opportunity to participate also in those conferences conducted in languages other than English. The ECPSA, as an umbrella organisation, could also encourage non-English speaking scholars to see themselves as part of the broader European political science community. The ECPR, on the other hand, would still be the main European political science organisation, but could benefit from working with the ECPSA. This would offer it a channel through which to reach a wider public of European political scientists, as the Confederation represents more European political scientists through its national 
associations than the ECPR does through its membership. In this sense, potential developments should be given priority over the existing situation.

A stable and legitimate political science with a clear identity and autonomous status, requires favourable political conditions (democracy) and economic conditions (resources), at the very least. International scholarly associations cannot directly influence these factors to any great degree. By offering a platform for scholars in countries where the discipline is undeveloped or under threat, international organisations can, however, help scholars in their struggle to enhance the discipline. Wider pan-European cooperation among political scientists would benefit everyone, and would hopefully lead to a fully institutionalised form of European political science in the future.

\section{REFERENCES}

Agapiou-Josephides, K. (2007). The Current State of Political Science in Cyprus. In H.-D. Klingemann (Ed.), The State of Political Science in Western Europe (pp. 73-86). Barbara Budrich Publishers.

Ágh, A. (1995). The Emergence of the "Science of Democracy" and Its Impact on the Democratic Transition in Hungary. In D. Easton, J. G. Gunnell, \& M. B. Stein (Eds.), Regime and Discipline. Democracy and the Development of Political Science (pp. 197-215). The University of Michigan Press.

Beyme, K. (1982). Federal Republic of Germany. In W. G. Andrews (Ed.), International Handbook of Political Science (pp. 169-176). Greenwood Press.

Bibic, A. (1985). The Development and Institutionalization of Political Science in Yugoslavia: From Periphery to the Center of Social Sciences. Unpublished Paper. Symposium on "Development and Institutionalization of Political Science: Center-Periphery and Other Crucial Concepts". The Finnish Political Science Association and the International Political Science Association. Espoo, Finland. Blondel, J. (1997). Amateurs into Professionals. In H. Daalder (Ed.), Comparative European Politics. The Story of a Profession (pp. 115-126). Pinter.

Blondiaux, L., \& Déloye, Y. (2007). The Current State of Political Science: Report on the Situation in France. In H.-D. Klingemann (Ed.), The State of Political Science in Western Europe (pp. 137-162). Barbara Budrich Publishers.

Boncourt, T. (2007). The Evolution of Political Science in France and Britain: A Comparative Study of Two Political Science Journals. European Political Science, 6(3), 276-294.

Boncourt, T. (2008). Is European Political Science Different from European Political Sciences? A Comparative Study of the European Journal of Political Research, Political Studies and the Revue Francaise de Science Politique 1973-2002. European Political Science, 7(3), 366-381. 
Boncourt, T. (2009). A History of the International Political Science Association. The International Political Science Association.

Boncourt, T. (2017). The Struggles for European Science. A Comparative Perspective on the History of European Social Science Associations. Serendipities, 2(1), 10-32.

Brintnall, M. (2004). What Are National Political Sciences and How Do Ideas Diffuse Among Them? Unpublished Paper. In The Conference for the Study of Political Thought. Tulane University.

Bull, M. J. (2007). Is There a European Political Science and, If So, What Are the Challenges Facing It? European Political Science, 6(4), 427-438.

Cairns, A. C. (1975). Political Science in Canada and the Americanization Issue. Canadian Journal of Political Science, 8(2), 191-234.

Coakley, J. (2004). The Organisational Evolution of Political Science: The International Dimension. International Social Science Journal, 56(179), 171-184.

Coakley, J., \& Laver, M. (2007). The Current State of Political Science in Ireland. In H.-D. Klingemann (Ed.), The State of Political Science in Western Europe (pp. 243-254). Barbara Budrich Publishers.

Coakley, J., \& Trent, J. (2000). History of the International Political Science Association 1949-1999. The International Political Science Association.

Daalder, H. (Ed.). (1997). Comparative European Politics. The Story of a Profession. Pinter.

Duverger, M. (1950). The Study of Political Institutions and Constitutional Law in France and in Its Present State of Advancement. In UNESCO (Ed.), Contemporary Political Science. A Survey of Methods, Research and Teaching (pp. 370-381). UNESCO.

Easton, D., Gunnell, J. G., \& Stein, M. B. (1995). Introduction: Democracy as a Regime Type and the Development of Political Science. In D. Easton, J. G. Gunnell, \& M. B. Stein (Eds.), Regime and Discipline. Democracy and the Development of Political Science (pp. 1-23). The University of Michigan Press.

Eisfeld, R., \& Pal, L. A. (2010a). Political Science in Central-East Europe and the Impact of Politics: Factors of Diversity, Forces of Convergence. In R. Eisfeld \& L. A. Pal (Eds.), Political Science in Central-East Europe. Diversity and Convergence (pp. 9-35). Barbara Budrich Publishers.

Eisfeld, R., \& Pal, L. A. (Eds.). (2010b). Political Science in Central-East Europe. Diversity and Convergence. Barbara Budrich Publishers.

Etherington, J., \& Morata, F. (2007). The Current State of Political Science in Spain. In H.-D. Klingemann (Ed.), The State of Political Science in Western Europe (pp. 325-339). Barbara Budrich Publishers.

European Political Science Network (epsNet). (2001). Constitution. epsNet. 
European Political Science Network (epsNet). (2003). 2002-2003 Membership Directory. epsNet.

Freddi, G., \& Giannetti, D. (2007). The Current State of Political Science in Italy. In H.-D. Klingemann (Ed.), The State of Political Science in Western Europe (pp. 255-274). Barbara Budrich Publishers.

Furlong, P. (2007). The European Conference of National Political Science Associations: Problems and Possibilities of Co-operation. In H.-D. Klingemann (Ed.), The State of Political Science in Western Europe (pp. 401-407). Barbara Budrich Publishers.

Goguel, F. (1950). Report on the Present State of the Study of Political Parties, Public Opinion and Elections in France. In UNESCO (Ed.), Contemporary Political Science. A Survey of Methods, Research and Teaching (pp. 503-514). UNESCO.

Goldsmith, M., \& Berndtson, E. (2002). Teaching Challenges for Political Science in Europe. European Political Science, 1(3), 69-80.

Grant, W. (2010). The Development of a Discipline: The History of the Political Studies Association. Wiley-Blackwell.

Jokic, M., Mervar, A., \& Mateljan, S. (2019). The Development of Political Science in Central and Eastern Europe: Bibliometric Perspective, 1996-2013. European Political Science, 18(3), 491-509.

Klingemann, H.-D. (2007a). A Comparative Perspective on Political Science in Western Europe around the Year 2005. In H.-D. Klingemann (Ed.), The State of Political Science in Western Europe (pp. 13-40). Barbara Budrich Publishers.

Klingemann, H.-D. (Ed.). (2007b). The State of Political Science in Western Europe. Barbara Budrich Publishers.

Klingemann, H.-D. (2008). Capacities. Political Science in Europe. West European Politics, 31(1-2), 370-396.

Kopelmanas, L. (1950). Teaching and Organization of Research in the Field of Political Science in France. In UNESCO (Ed.), Contemporary Political Science. A Survey of Methods, Research and Teaching (pp. 647-654). UNESCO.

Krauz-Mozer, B., Kulakowska, M., Borowiec, P., \& Scigaj, P. (2015a). Political Science at the Dawn of the 21 st Century. In B. Krauz-Mozer, M. Kulakowska, P. Borowiec, \& P. Scigaj (Eds.), Political Science in Europe at the Beginning of the 21st Century (pp. 9-18). Jagiellonian University Press.

Krauz-Mozer, B., Kulakowska, M., Borowiec, P., \& Scigaj, P. (Eds.). (2015b). Political Science in Europe at the Beginning of the 21st Century. Jagiellonian University Press.

McGrath, C. (2008). Increasing Co-operation Among Political Science Associations in Europe. European Political Science, 7(3), 352-365.

Newton, K., \& Vallès, J. (1991). Introduction: Political Science in Western Europe, 1960-1990. European Journal of Political Research, 20(3-4), 227-238. 
Pedersen, M., \&Grunberg, G. (1998). Analytical Paper (Appendix 2). Unpublished. Meeting of November 28th, 1998. Paris.

Quermonne, J-L. (Director). (1996). La Science Politique en Europe: Formation, Coopération, Perspectives. Fondation Nationale des Sciences Politiques.

Robson, W. A. (1950). Political Science in Great Britain. In UNESCO (Ed.), Contemporary Political Science. A Survey of Methods, Research and Teaching (pp. 294-312). UNESCO.

Rose, R. (1990). Institutionalizing Professional Political Science in Europe: A Dynamic Model. European Journal of Political Research, 18(6), 581-603.

Salvadori, M. (1950). Introduction. In UNESCO (Ed.), Contemporary Political Science. A Survey of Methods, Research and Teaching (pp. 1-20). UNESCO.

Schüttemeyer, S. S. (2007). The Current State of Political Science in Germany. In H.-D. Klingemann (Ed.), The State of Political Science in Western Europe (pp. 163-183). Barbara Budrich Publishers.

Stein, M. B. (1995). Major Factors in the Emergence of Political Science as a Discipline in Western Democracies: A Comparative Analysis of the United States, Britain, France, and Germany. In D. Easton, J. G. Gunnell, \& M. B. Stein (Eds.), Regime and Discipline. Democracy and the Development of Political Science (pp. 169-195). The University of Michigan Press.

Tarkowski, J. (1987). Political Science and Sociology: Different Responses to the Polish Crisis. Unpublished Paper. Round Table on "The Comparative Study of the Development of Political Science". The International Committee for the Study of the Development of Political Science and the Center of Political Science, Feltrinelli Foundation. Cortona, Italy.

Topf, R. (2007). The European Political Science Network. In H.-D. Klingemann (Ed.), The State of Political Science in Western Europe (pp. 417-424). Barbara Budrich Publishers.

UNESCO. (1950). Political Science. A Survey of Methods, Research and Teaching. UNESCO.

Wemegah, M. (with the collaboration of Frei, D.) (1982). Switzerland. In W. G. Andrews (Ed.), International Handbook of Political Science (pp. 327-335). Greenwood Press.

Wiatr, J. J. (1995). The Impact of Democratization on Political Science in Poland. In D. Easton, J. G. Gunnell, \& M. B. Stein (Eds.), Regime and Discipline. Democracy and the Development of Political Science (pp. 217-228). The University of Michigan Press.

Wittrock, B. (1985). Dinosaurs or Dolphins? Rise and Resurgence of the ResearchOriented University. In B. Wittrock \& A. Elzinga (Eds.), The University Research System. The Public Policies of the Home of Scientists (pp. 13-37). Almqvist \& Wiksell. 


\section{Websites}

European Confederation of Political Science Associations (ECPSA). Retrieved April 29, 2020, from https://www.ecpsa.org/

European Consortium for Political Research (ECPR). Retrieved April 29, 2020; 10 June 2020; 15 June 2020, from https://www.ecpr.eu/

European Research Council (ERC). Retrieved April 29, 2020, from https://erc. europa.eu/

International Political Science Association (IPSA). Retrieved April 29, 2020, from https://www.ipsa.org/

Professionalization and Social Impact of European Political Science (PROSEPS). Retrieved June 15, 2020, from https://proseps.unibo.it/

Open Access This chapter is licensed under the terms of the Creative Commons Attribution 4.0 International License (http://creativecommons.org/licenses/ by $/ 4.0 /$ ), which permits use, sharing, adaptation, distribution and reproduction in any medium or format, as long as you give appropriate credit to the original author(s) and the source, provide a link to the Creative Commons licence and indicate if changes were made.

The images or other third party material in this chapter are included in the chapter's Creative Commons licence, unless indicated otherwise in a credit line to the material. If material is not included in the chapter's Creative Commons licence and your intended use is not permitted by statutory regulation or exceeds the permitted use, you will need to obtain permission directly from the copyright holder.

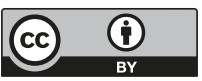

